\title{
Genetic Variation in Past and Current Landscapes: Conservation Implications Based on Six Endemic Florida Scrub Plants
}

\author{
Eric S. Menges, ${ }^{1}$ Rebecca W. Dolan, ${ }^{2}$ Roberta Pickert, ${ }^{1}$ Rebecca Yahr, ${ }^{3}$ and Doria R. Gordon ${ }^{4}$ \\ ${ }^{1}$ Archbold Biological Station, P.O. Box 2057, Lake Placid, FL 33862, USA \\ ${ }^{2}$ Friesner Herbarium, Butler University, 4600 Sunset Ave., Indianapolis, IN 46208, USA \\ ${ }^{3}$ Royal Botanic Garden Edinburgh, 20A Inverleith Row, EH3 5LR, Edinburgh Scotland, UK \\ ${ }^{4}$ The Nature Conservancy, Department of Botany, University of Florida, P.O. Box 118526, Gainesville, FL 32611, USA \\ Correspondence should be addressed to Eric S. Menges, emenges@archbold-station.org
}

Received 29 May 2009; Revised 9 December 2009; Accepted 18 January 2010

Academic Editor: Bradford Hawkins

Copyright () 2010 Eric S. Menges et al. This is an open access article distributed under the Creative Commons Attribution License, which permits unrestricted use, distribution, and reproduction in any medium, provided the original work is properly cited.

If genetic variation is often positively correlated with population sizes and the presence of nearby populations and suitable habitats, landscape proxies could inform conservation decisions without genetic analyses. For six Florida scrub endemic plants (Dicerandra frutescens, Eryngium cuneifolium, Hypericum cumulicola, Liatris ohlingerae, Nolina brittoniana, and Warea carteri), we relate two measures of genetic variation, expected heterozygosity and alleles per polymorphic locus (APL), to population size and landscape variables. Presettlement areas were estimated based on soil preferences and GIS soils maps. Four species showed no genetic patterns related to population or landscape factors. The other two species showed significant but inconsistent patterns. For Liatris ohlingerae, APL was negatively related to population density and weakly, positively related to remaining presettlement habitat within $32 \mathrm{~km}$. For Nolina brittoniana, APL increased with population size. The rather weak effects of population area/size and both past and current landscape structures suggest that genetic variation needs to be directly measured and not inferred for conservation planning.

\section{Introduction}

Protecting plant genetic variation is a conservation goal [1], as genetic variation reflects phylogenetic and population history, which is associated with fitness and evolutionary potential $[2,3]$, and can influence ecosystem processes $[4,5]$. While neutral genetic variation is not directly linked to quantitative genetic traits [6], it may be significantly correlated to fitness [7]. If a large percentage of population-level genetic variation (as measured by values such as expected heterozygosity and alleles per polymorphic locus) could be predicted from such ecological and landscape measures as population size, isolation, and nearby suitable habitat, then conservation decisions intended to protect genetic variation could be made without the need for collection of costly and time-consuming molecular data.

This study focuses on several factors potentially affecting within-species genetic patterns. At the species level, genetic variation tends to be relatively low for endemics as compared to broadly distributed species [8]. Endemics of the southeastern U.S. tended to have higher genetic diversity at both species and population levels than endemics in general [9]. Within species, population-level genetic variation is affected by life history, being slightly higher in outcrossing species [8]. A recent meta-analysis shows that habitat fragmentation tends to reduce genetic variation, with similar effects sizes for several measures of genetic variation [10]. More specifically, some (but not all) individual studies have shown greater intraspecific genetic variation in larger [3, 11-15], denser [16], or less-isolated [17-20] populations. Other patterns include lower genetic variation in degraded and logged habitats [21], clines in allele frequencies [22, 23] discontinuities among geographically-separated portions of the range $[18$, 24] or between organisms separated by landscape barriers [25], higher variation in unglaciated portions of species' ranges [26], higher genetic variation in core versus marginal populations [27-30], and differences in genetic variation between distinct habitats (prairie versus alvar) [31]. Studies 
considering the effects of original habitat patch size, current patch size, population area, and areas of nearby suitable habitat within the landscape on local genetic variation are less common but also show positive relationships [32, 33]. In general, habitat fragmentation tends to decrease genetic variation of remaining populations [34].

For the endemic-rich Florida scrub $[35,36]$, such genetic patterns have been investigated for animals $[37,38]$ but not for plants. Florida scrub is a pyrogenic shrubland dominated by long-lived woody plants, although most of its endemic species are shorter-lived subshrubs and herbs [39]. Previous genetic studies of a range of Florida scrub species have focused on comparisons of species or varieties without consideration of landscape structure [24, 40-47]. In this paper, we consider the effects of landscape structure on genetic variation for six species of plants in Florida scrub with different spatial distributions and life histories.

Florida scrub species were probably never distributed in a continuous fashion within their ranges due to specializations for soil type [54], fire regime [39], canopy gaps [55], and soil drainage [56], as well as the stochastic nature of their metapopulation dynamics [57]. Habitat for these scrub endemics has likely been naturally patchy to different degrees due to low ocean levels during the Pleistocene [58]. However, recent agricultural and urban developments have decreased extent and connectivity of Florida scrub. Only 13\% of the original xeric uplands on the Lake Wales Ridge remain (for 2003 , calculated from [59]), down from the estimate of $36 \%$ made roughly 20 years earlier (calculated from [60]). Despite this ongoing loss, effects of habitat loss and fragmentation on genetic variation of Florida scrub plants have not previously been examined.

The study six species Warea carteri Small (Brassicaceae) [52, 61], Eryngium cuneifolium Small (Apiaceae) [49], Hypericum cumulicola (Small) W.P. Adams (Clusiaceae) [50], Dicerandra frutescens Shinners (Lamiaceae) [48], Nolina brittoniana Nash (Agavaceae) [44], and Liatris ohlingerae (S.F. Blake) B.L. Rob. (Asteraceae) [51]) vary considerably in demography, reproductive biology, and habitat requirements (Table 1). Like many studied Florida scrub plants, the six subjects of this paper show variation in edaphic specialization: D. frutescens and E. cuneifolium are soil specialists, while L. ohlingerae, $H$. cumulicola, $N$. brittoniana, and $W$. carteri have more generalized soil preferences [8]. Seed dispersal is passive for most of our study species, and dispersal distances tend to be short [44].

Our prior isozyme genetic studies have focused largely on genetic differences among species. We found that five of these six species (D. frutescens, E.cuneifolium, H. cumulicola, $N$. brittoniana, and $W$. carteri but not L. ohlingerae) had lower genetic variation than that found in comparable endemic species elsewhere. Values of $H_{e}$ ranged from 0.12 for $L$. ohlingerae to less than 0.06 for E. cuneifolium, D. frutescens, $W$. carteri, and H. cumulicola [44]. Population differentiation $\left(F_{s t}\right)$ was particularly high for $H$. cumulicola $(0.72)$ and ranged from 0.03 to 0.44 for other species [44].

Among the six species, levels of genetic variation were higher in species with greater demographic stability but were not related to geographic range size, habitat specificity, or seed dispersal distances [44]. Nolina brittoniana and W. carteri exhibited clines in allele frequencies along the major (north-south) axis of their ranges [47, 53].

In this paper, we test whether within-species populationlevel genetic variation is related to variables such as population size and nearby available habitat. We define available habitat by suitable soils (see below). We use geographic information systems (GIS) to summarize and analyze landscape patterns of current populations, and the locations and sizes of presettlement and extant soil patches that support, or could support, each of the six species. We then relate these variables to patterns of population-level genetic variation determined from allozyme electrophoresis, using new analyses of previously published data $[43,44]$.

In developing the appropriate data for this suite of species, we hope to both inform current conservation programs for Florida scrub and develop more general conclusions to support decisions for other suites of narrowly endemic plant species that have received less examination. While smaller scale processes undoubtedly contribute to patterns in observed genetic variation [62], these landscape scale features are often used as surrogates for identifying population targets for conservation efforts [63-65]. Additional empirical studies of multiple species in the same landscape are needed to confirm the validity of this approach [87].

We hypothesize that the six Florida scrub species under study will have greater genetic variation in larger populations on larger habitat patches (both extant and presettlement), in populations with more past or extant suitable habitat in the vicinity, and in presettlement patches that have retained larger proportions of intact area. Finally, because current genetic patterns may not yet be in equilibrium with land use changes, we hypothesize that genetic variation will be more closely related to presettlement than to extant landscape structure.

\section{Methods}

2.1. Sites, Population Sizes, and Tissue Collections. Sites for tissue collections and population size estimates were chosen using distributional data from the Florida Natural Areas Inventory and Archbold Biological Station. We chose sites across the species ranges (Figure 1), collecting tissue from populations separated by at least $1.7 \mathrm{~km}$. Over a three year period, we sampled 164 populations (13-48 per species; Table 2) from sites across five counties in central Florida (Highlands, Lake, Orange, Osceola, and Polk) and three ridges (Lake Wales, Winter Haven, and Orlando). This sample included the majority of the known occurrences of most study species. Most samples come from the Lake Wales Ridge [66] in Highlands and Polk counties where there are more protected sites [59, 67].

We estimated population size using a variety of techniques. Smaller populations (generally $<200$ individuals) were fully censused. We sampled larger populations using belt transects, 2-4 $\mathrm{m}$ wide, placed in stratified random fashion to cover the entire area of the population. This sample was then extrapolated to the total population size 
TABLE 1: Biological information on our study species.

\begin{tabular}{|c|c|c|c|c|c|c|}
\hline Species & $\begin{array}{c}\text { Life Span and } \\
\text { Life Form* }\end{array}$ & $\begin{array}{l}\text { Postfire } \\
\text { Recovery }\end{array}$ & Habitat & $\begin{array}{c}\text { Primary } \\
\text { Pollinators } \\
\text { (distance) } \\
{[39]} \\
\end{array}$ & $\begin{array}{l}\text { Mating } \\
\text { System }\end{array}$ & Citations \\
\hline $\begin{array}{l}\text { Dicerandra } \\
\text { frutescens }\end{array}$ & SL, PSS & Seed Bank & Florida scrub & $\begin{array}{c}\text { Bee-Fly } \\
\text { (long) }\end{array}$ & Mixed & {$[48]$} \\
\hline $\begin{array}{l}\text { Eryngium } \\
\text { cuneifolium }\end{array}$ & SL, PH & Seed Bank & Florida scrub & $\begin{array}{l}\text { Generalist } \\
\text { Insects } \\
\text { (variable) }\end{array}$ & Mixed & {$[49]$} \\
\hline $\begin{array}{l}\text { Hypericum } \\
\text { cumulicola }\end{array}$ & SL, PH & Seed Bank & Florida scrub & Bees (short) & Mixed & {$[50]$} \\
\hline $\begin{array}{l}\text { Liatris } \\
\text { ohlingerae }\end{array}$ & $\mathrm{LL}, \mathrm{PH}$ & Resprout & Florida scrub & $\begin{array}{l}\text { Butterflies } \\
\text { (long) }\end{array}$ & Outcrossing & {$[51]$} \\
\hline $\begin{array}{l}\text { Nolina } \\
\text { brittoniana }\end{array}$ & LL, PH & Resprout & $\begin{array}{l}\text { Sandhill, } \\
\text { Florida Scrub }\end{array}$ & $\begin{array}{c}\text { Generalist } \\
\text { Insects (long) }\end{array}$ & Outcrossing & {$[44]$} \\
\hline Warea carteri & A & Seed Bank & $\begin{array}{l}\text { Sandhill, } \\
\text { Florida Scrub }\end{array}$ & $\begin{array}{c}\text { Generalist } \\
\text { Insects } \\
\text { (variable) }\end{array}$ & $\begin{array}{l}\text { Mixed, High } \\
\text { Self }\end{array}$ & {$[52,53]$} \\
\hline
\end{tabular}

*SL: short lived (<10 years), LL: long lived (>10 years), PSS: perennial subshrub, and PH: perennial herb, A: annual.

TABLE 2: Variables significant $(P<.05)$ in predicting two measures of genetic variation, Alleles per Polymorphic Locus $($ APL) and Expected Heterozygosity $\left(H_{e}\right)$, in multiple regressions. $N_{p}$ refers to number of populations, $N_{i}$ refers to mean number of individuals sampled and scored per population. Variables were variously transformed before correlation analysis (see text). Beta is the standardized regression coefficient, $P$ refers to significance in model with all significant variables included.

\begin{tabular}{|c|c|c|c|c|c|c|c|c|}
\hline Species & $N_{p}$ & $N_{i}$ & $F_{\text {st }}$ & Genetic Variation Measure & Mean & Predictor Variable & Beta & $P$ \\
\hline \multirow{2}{*}{ Dicerandra frutescens } & \multirow{2}{*}{13} & \multirow{2}{*}{29} & \multirow{2}{*}{0.030} & APL & 3.58 & None & & \\
\hline & & & & $H_{e}$ & 0.031 & None & & \\
\hline \multirow{2}{*}{ Eryngium cuneifolium } & \multirow{2}{*}{16} & \multirow{2}{*}{30} & \multirow{2}{*}{0.445} & APL & 2.00 & None & & \\
\hline & & & & $H_{e}$ & 0.054 & None & & \\
\hline \multirow{2}{*}{ Hypericum cumulicola } & \multirow{2}{*}{34} & \multirow{2}{*}{28} & \multirow{2}{*}{0.724} & APL & 2.02 & None & & \\
\hline & & & & $H_{e}$ & 0.023 & None & & \\
\hline \multirow{3}{*}{ Liatris ohlingerae } & \multirow{3}{*}{28} & \multirow{3}{*}{22} & \multirow{3}{*}{0.120} & \multirow{2}{*}{ APL } & \multirow{2}{*}{2.43} & Density & -0.087 & .003 \\
\hline & & & & & & Extant: $32 \mathrm{~km}$ & +0.250 & .033 \\
\hline & & & & $H_{e}$ & 0.121 & None & & \\
\hline \multirow{2}{*}{ Nolina brittoniana } & \multirow{2}{*}{48} & \multirow{2}{*}{25} & \multirow{2}{*}{0.411} & APL & 2.53 & Population Size & +0.488 & .009 \\
\hline & & & & $H_{e}$ & 0.069 & None & & \\
\hline \multirow{2}{*}{ Warea carteri } & \multirow{2}{*}{23} & \multirow{2}{*}{25} & \multirow{2}{*}{0.304} & APL & 2.30 & None & & \\
\hline & & & & $H_{e}$ & 0.025 & None & & \\
\hline
\end{tabular}

by estimating the area. Population edges were determined by inappropriate habitat for the species, or by $\mathrm{a} \geq 50 \mathrm{~m}$ break between plants. For the clonal Nolina brittoniana, we considered individuals as rosettes that were at least $1 \mathrm{~m}$ apart, based on patterns of allozyme genotypes [47].

Leaves (or flower buds in the case of H. cumulicola) were collected for allozyme analysis at the same time population size estimates were made. For populations of fewer than 30 plants, leaves or buds were collected from all individuals. For larger populations, we collected leaves from 30 individuals randomly selected but stratified by spatial location. Thus, variation in sample size reflects variation in observed population size, not in sampling effort. Sample sizes for numbers of individuals sampled and scored per population were generally $>20$ (Table 2 ). Standard genetic parameters, including percent of polymorphic loci, number of alleles per locus, and expected heterozygosity, were calculated for each population, using the software package Biosys [68]. We also hand calculated the number of alleles per polymorphic locus. Details of allozyme procedures and results for individual species are given in several papers $[43,47,69]$.

2.2. Defining Suitable Soil Types. Soil properties are an important dimension of the habitat for many species [70, 71]. For these Florida scrub species, soil requirements are well known and quite specific [54]. We defined suitable soil types based on the intersection of known species locations with digital $(1: 24,000$ scale) soil maps prepared by the Soil Conservation Service [54]. All the suitable soils are 


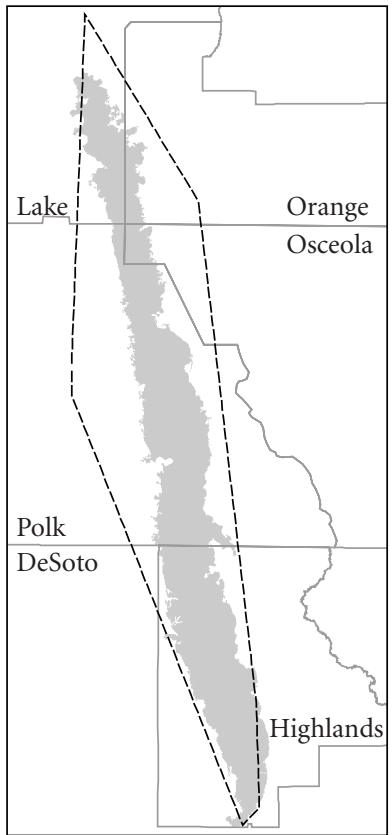

Nolina brittoniana

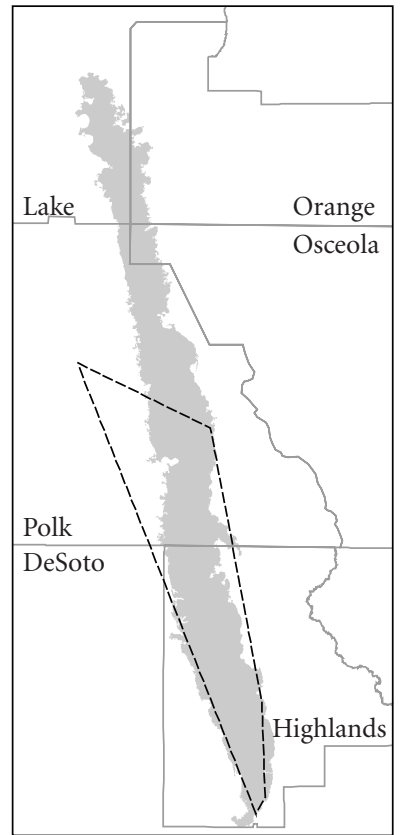

Liatris ohlingerae
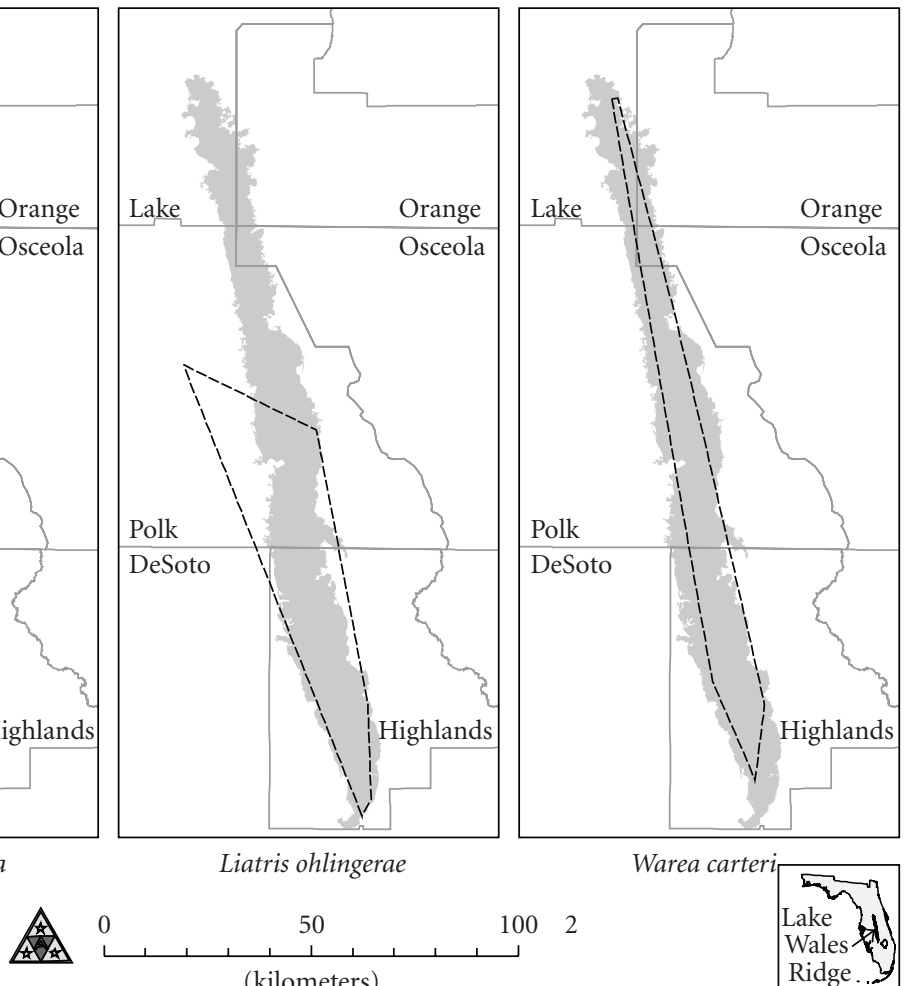
1002
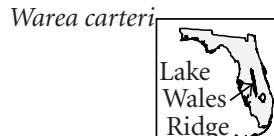

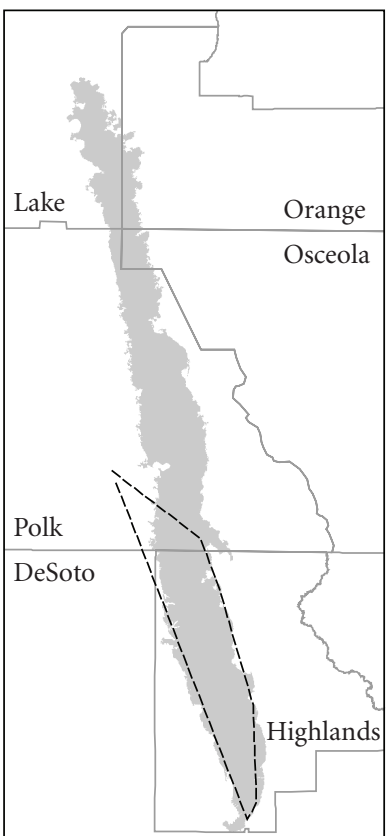

Hypericum cumulicola

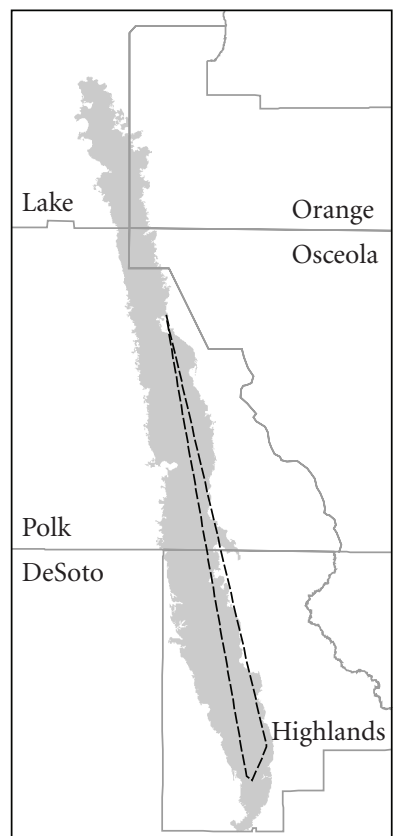

Dicerandra frutescens

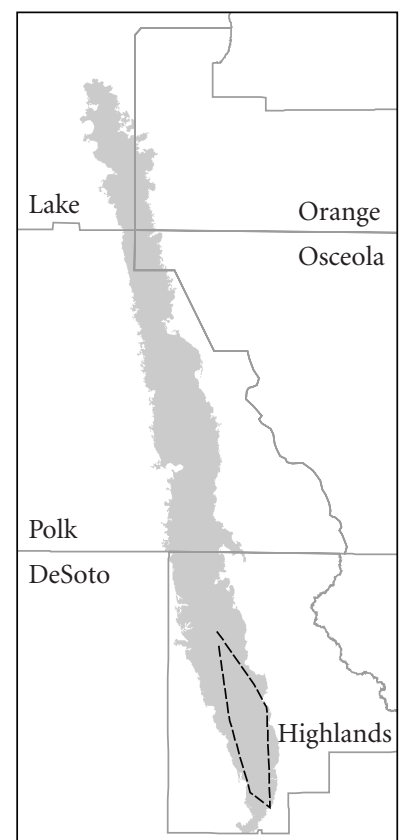

Eryngium cuneifolium

FIGURE 1: Minimum convex polygons for distributions of six study species on the Lake Wales Ridge in central Florida.

hyperthermic, uncoated Typic or Spodic Haplaquolls [72]: sandy, low-nutrient soils that vary in soil color and distance from the water table. Eryngium cuneifolium, H. cumulicola, and $L$. ohlingerae were found primarily on white (St. Lucie and Archbold sands) and gray (Satellite, Duette, Daytona, and Pomello sands) sands [54]; these soils were defined as suitable in the current study. The gray sands have a higher water table than the white sands. Likewise, $D$. frutescens is a specialist for yellow sands with a deep water table (Paola, Astatula, Tavares, and Orsino sands) [54] and these soils were considered suitable habitat. Warea carteri is a soil generalist [54], with yellow and gray sands suitable, and N. brittoniana occurs over a wide range of soil types [54], with white, gray, and yellow colored sands suitable. Less than $20 \%$ of 
the known occurrences, by species, fall outside these soil classifications [54].

For this analysis, we defined suitable habitat entirely based on soil preferences. Weather data (temperature, precipitation) are available on a $\mathrm{km}$ scale, but soil divisions occur on a much finer $(\mathrm{m})$ scale. In addition, temperature and precipitation variation across our study area is minimal. For example, maps of 17 hydrologic variables (rainfall, humidity, and evaporation) show less than $5 \%$ variation over the study area [73]. Similarly, this area shows very little variation in temperature variables [74]. Fire history also affects whether a habitat patch is suitable for individual scrub species $[48,54]$ but it was not available for all our study sites. Likewise, colonization history would affect which habitat patches would be out of dispersal range, but we lack these data as well.

2.3. Analytical Methods. We used ARCINFO 9.1 software and aerial photographs to create a number of spatial coverages for each species: the populations from which genetic collections were made, extant home polygons, and other polygons with suitable habitat. The home polygon was defined as the merger of the soil polygon from which the collection was made with all adjoining extant suitable soil polygons. For example, if the home polygon is a polygon of Archbold sand, we merged it with adjoining polygons of the similar St. Lucie white sand, both of which are suitable habitat for white sand species. Likewise, we merged adjoining soil polygons with similarly suitable habitat across the landscape. These mergers were made separately for the presettlement and extant landscapes. Presettlement areas were inferred from all suitable soils; extant areas of suitable soils were digitized from aerial photographs. Extant areas included all intact habitat patches, including disturbed habitats (considered potential habitat for the study species), but excluded patches converted to housing, citrus, industry, or pasture. These coverages show that individual populations have experienced a wide range of habitat loss and fragmentation of nearby habitats (Figure 2).

We used GIS to calculate the areas of suitable habitat (either extant or presettlement) within 2,8 , and $32 \mathrm{~km}$ of the boundary of the extant or presettlement home polygon. We buffered in this way rather than buffering around the exact collection points (as in [75]) for two reasons. First, buffering the point would have included parts of the home polygon, which we intended as a separate variable. Second, we assumed that much of the polygon was occupied by the population (at one time or another) so that the landscape as seen from the habitat edges was most relevant in affecting landscape genetic structure.

We originally identified a total of 20 predictor variables. For both presettlement and extant landscapes, we calculated soil patch sizes and areas and proportions of remaining suitable soils within radii of $2 \mathrm{~km}, 8 \mathrm{~km}$, and $32 \mathrm{~km}$ (Figure 2). We also calculated proportions of original patches remaining and current population size, area, and density and the shortest distance from the collection point to the patch edge. Finally, we calculated isolation indices for each presettlement and extant patch using the formula of Hanski and Thomas [76] for all patches within $32 \mathrm{~km}$. Individual variables were transformed to improve their fit to assumptions of correlation analysis and multiple regression.

Within and among species, we noted many strong correlations among these transformed predictor variables. We therefore reduced the predictor variables to a set of seven relatively independent (absolute value of $r<0.42$ ) variables: population size, population density, extant patch area, extant area within $32 \mathrm{~km}$, distance to patch edge, presettlement isolation index, and extant isolation index.

For each population, we summarized genetic variation as expected heterozygosity and the number of alleles per polymorphic locus. Other measures of genetic variation (percent of polymorphic loci, observed heterozygosity) had strong correlations with these two measures for most of our study species.

To evaluate the relationship of the set of seven transformed predictor variables to expected heterozygosity and alleles per polymorphic locus, we performed forward stepwise multiple regressions for each species. Alleles per polymorphic locus did not vary among populations for Eryngium cuneifolium, so no analysis was done. All analyses were accomplished using SPSS version 11.5.0 [77].

\section{Results}

Genetic variation was generally poorly predicted by population and landscape variables (Table 2). For four of the six species (D. frutescens, E. cuneifolium, H. cumulicola, and $W$. carteri), we found no significant relationships between genetic variation and predictor variables (Table 2). For the other two species (L. ohlingerae and N. brittoniana), there were only two significant regressions, those predicting alleles per polymorphic locus. Although for one species ( $L$. ohlingerae) the area within a buffer was a predictor of genetic variation, in no cases did isolation indices predict genetic variation (Table 2). No regressions successfully predicted expected heterozygosity from population and landscape variables for any of our six study species.

For L. ohlingerae, the number of alleles per polymorphic locus were lower in high density populations and higher in populations with larger areas of habitat remaining extant within $32 \mathrm{~km}$ (Table 2). The negative relationship between alleles per polymorphic locus and density (Figure 3 ) was opposite to that predicted. Conversely, the weak but positive relationship between area within $32 \mathrm{~km}$ in alleles per polymorphic locus (Figure 4) was consistent with our prediction. The two variables together predicted about one third of the variation in alleles per polymorphic locus $\left(r^{2}=0.34\right)$.

For N. brittoniana, the species with the largest number of populations, alleles per polymorphic locus was higher for larger extant populations (Table 2, Figure 5), although this relationship explained less than $15 \%$ of the variation $\left(r^{2}=0.14\right)$. 


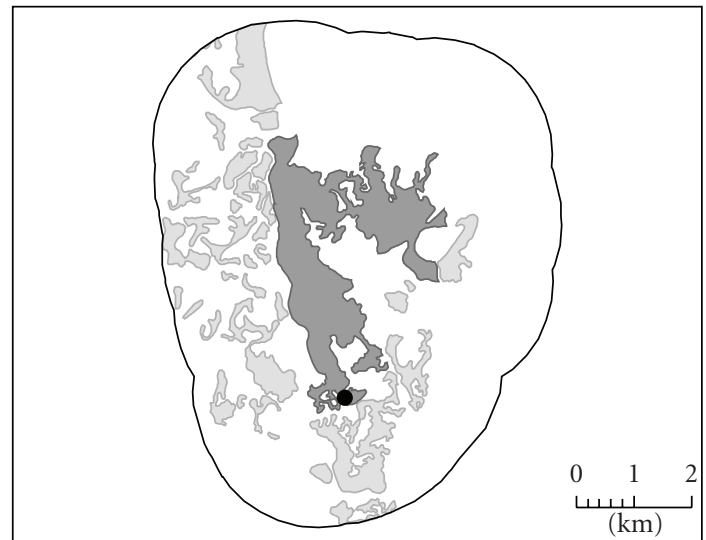

(a)

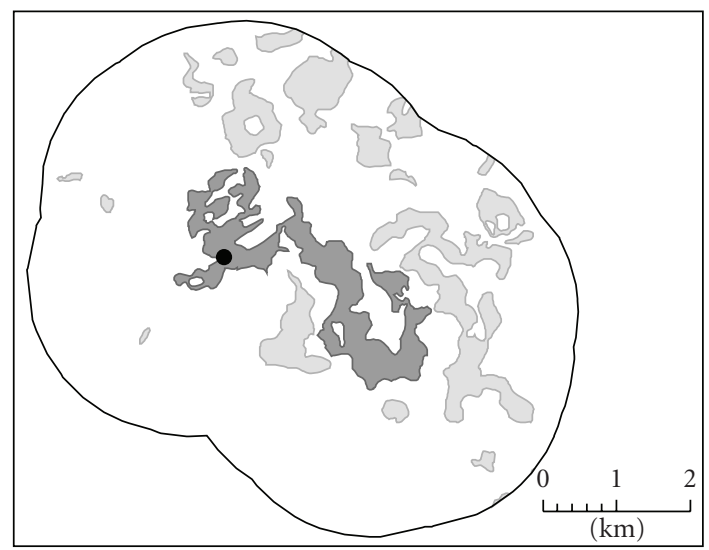

(c)

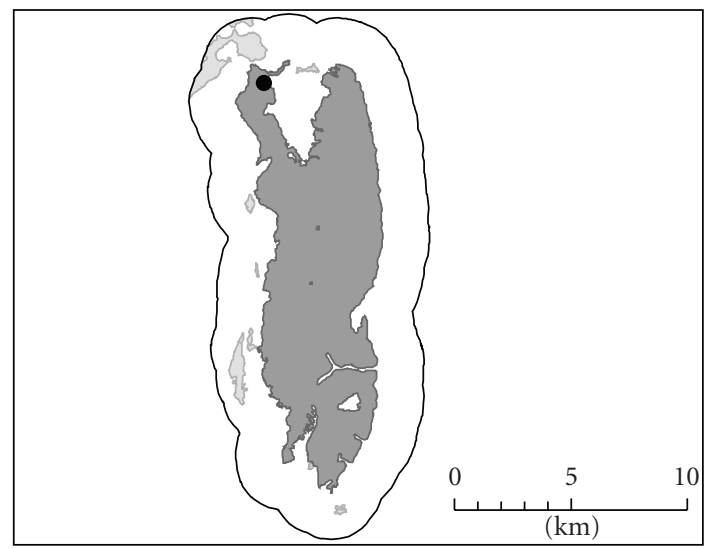

(e)

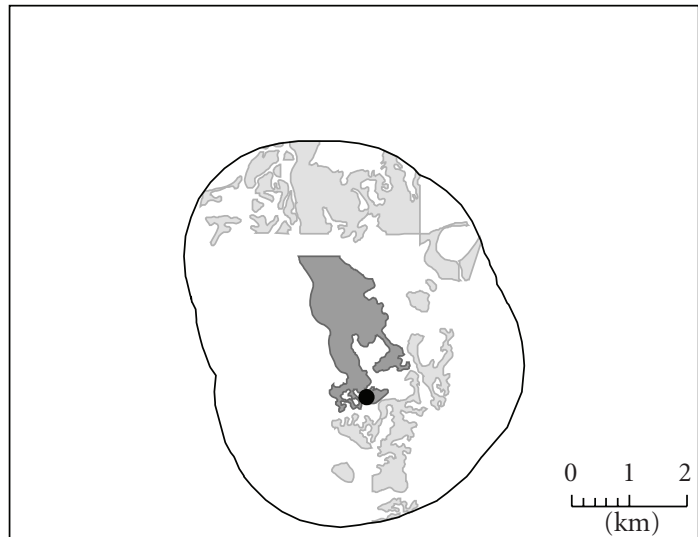

(b)

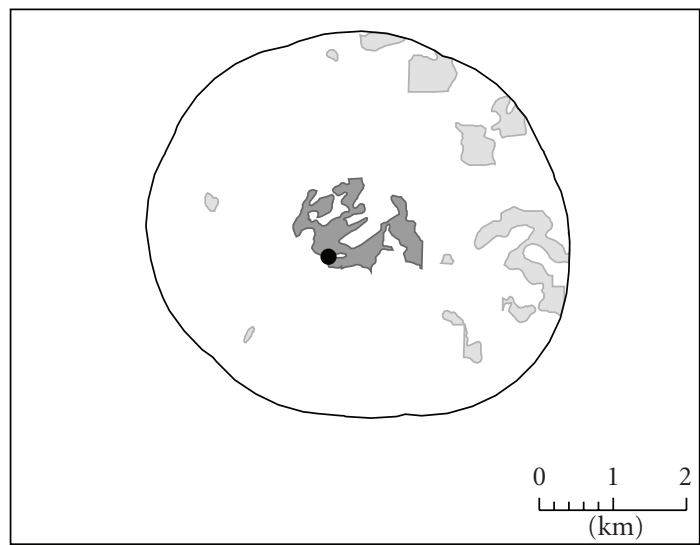

(d)

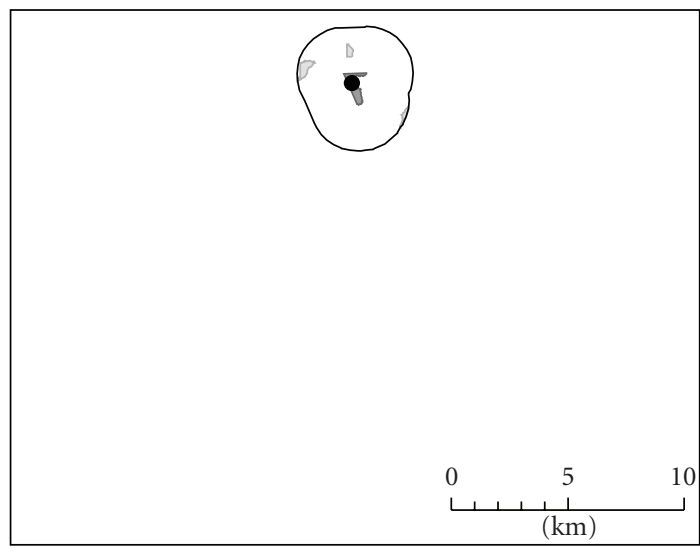

(f)

FIGURE 2: Landscape structure around three representative populations sampled for genetic variation. In each case, the location of the genetic sample is shown by the filled circle, the dark polygon represents the home polygon of the sample (with the home polygon being the soil polygon from which the genetic collection was made merged with all adjoining suitable soil polygons), and the light shading represents suitable soil polygons within the $2 \mathrm{~km}$ buffer (shown as a dark line). (a, b) presettlement and extant landscapes, respectively, for Liatris ohlingerae at Archbold Biological Station West. The population is protected and nearby habitat loss and fragmentation is moderate. (c, d) presettlement and extant landscapes, respectively, for Hypericum cumulicola at Lizzie Lake. The population is unprotected and nearby habitat loss and fragmentation is high. (e, f) presettlement and extant landscapes, respectively, for Dicerandra frutescens at Camp Florida. The population is unprotected and nearby habitat loss and fragmentation is extreme. 


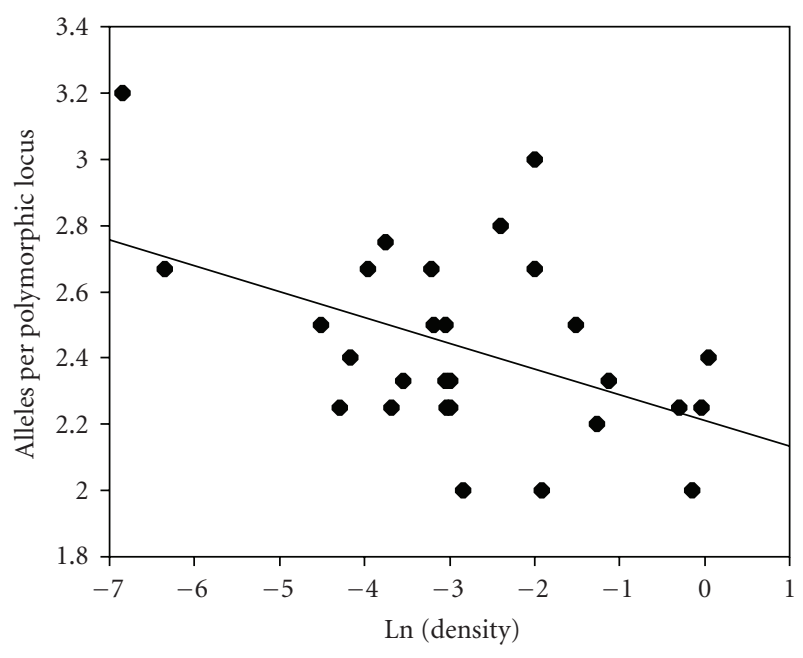

FIgURe 3: Alleles per polymorphic locus as a function of the natural $\log$ of population density per $\mathrm{m}^{2}$, for Liatris ohlingerae. $r=-0.465$, $P=.010$.

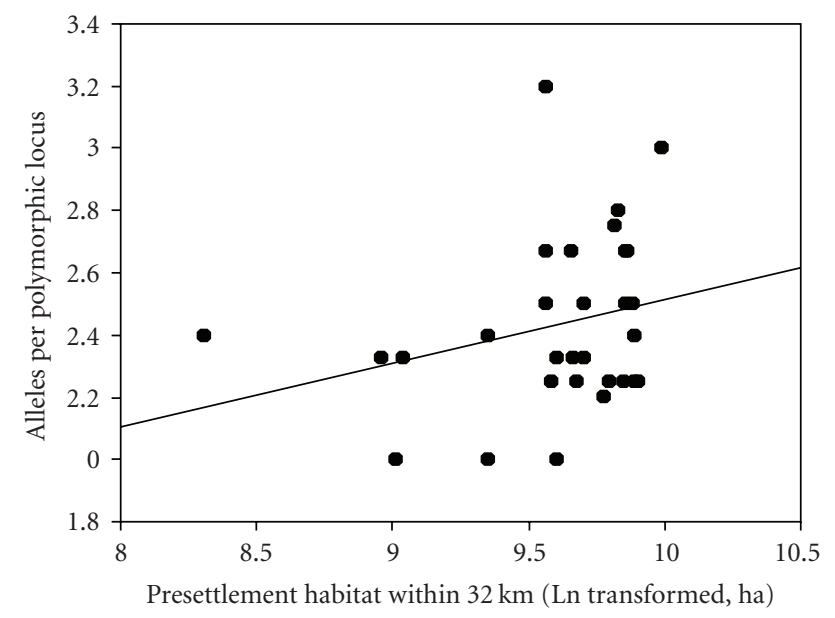

FIGURE 4: Alleles per polymorphic locus as a function of the amount of presettlement habitat remaining within $32 \mathrm{~km}$ (ha, Ln scale), for Liatris ohlingerae. $r=0.264, P=.158$. When used in multiple regression, this relationship was significant (Table 1).

\section{Discussion}

4.1. Genetic Patterns in Florida Landscapes. The conservation biology literature often predicts that population-level genetic variation will be positively correlated with population size [3, $14,78]$ and the size and proximity of habitat patches $[17,18$, 79]. These predictions were completely unsupported for our six Florida scrub species based on expected heterozygosity. Patterns based on alleles per polymorphic locus were weak.

Our only clonal study species, $N$. brittoniana, was one of the more genetically variable species and the only one that showed genetic patterns with population size. Although clonal spread does not provide for recombination and might be expected to suppress population-level genetic variation, some clonal species are genetically diverse $[80,81]$. However,

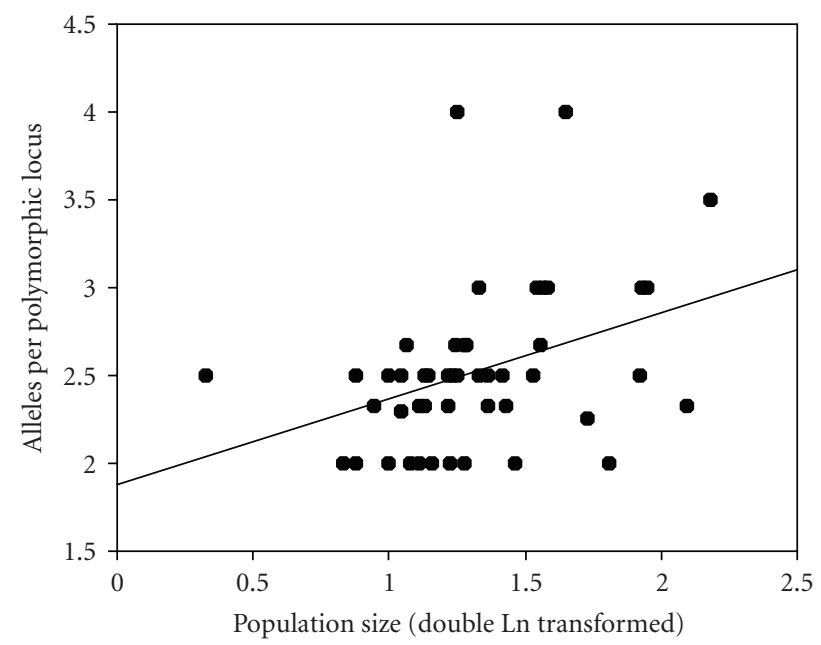

Figure 5: Alleles per polymorphic locus as a function of the population size (double natural log transformed), for Nolina brittoniana. $r=0.376, P=.009$.

clonal species that cannot reproduce sexually may have very limited genetic variation $[46,82]$. The genetic variation we observed in $N$. brittoniana suggests that occasional seedling recruitment must occur in this species, although seedlings are virtually unknown. If seedling recruitment and genetic diversity are mutually re-enforcing, this may explain the positive relationship of genetic variation and population size observed in this species.

For butterfly-pollinated L. ohlingerae, density was negatively related to genetic variation. One observation to explain this result may be that pollinators travel longer distances in less dense populations [83, 84], effectively increasing outcrossing. Density has effects on spatial genetic structure in other populations [85].

Why did we find such weak correlation between genetic variation and landscape variables? Because a great deal of habitat fragmentation in central Florida has occurred in the last few decades, the general lack of a population size effect on genetic variation in our study may be due to the lag time between population reductions due to habitat fragmentation and genetic deterioration [86, 87]. Habitat loss and degradation might be slow to impact genetic diversity (compared to impacts on inbreeding, reproductive output, and fitness), as found in an analysis of studies of neotropical tree species [87]. Fragmentation effects increase with the number of generations for plant populations $[6,10]$.

To better resolve the complex links between landscape variables and genetic variation $[1,88]$, we clearly separated population size variables and variables related to isolation in our study (as recommended by Ouborg et al. [13]). The complex habitat patch shapes for our species resulted in isolation indices for individual habitat patches were often idiosyncratic, being heavily weighted by the presence of nearby, large habitat fragments. Idiosyncratic relationships of genetic variation to land use history have been found in other studies [75] and may have affected our analyses. 
Genetic patterns will also clearly be influenced by differences in the life histories, evolutionary trajectories, and ecological adaptations of each species. Fragmentation effects are greatest for common or recently rare (versus naturally rare) species and for outcrossing (versus selfing) plants [10]. Our previous analysis showed that the amount of genetic variation among these species (being highest in L. ohlingerae and N. brittoniana) was consistent with species rankings for life span, demographic stability, an outcrossing breeding system, and longer pollinator dispersal distances [44]. Population differentiation was highest in H. cumulicola, which was attributed to its specialized pollination syndrome and the inferred modest movement patterns of its bee pollinators [44].

The lack of general patterns detected in our study may also reflect the stochastic and dynamic nature of most of these species. Current population size and distribution are likely not in equilibrium and may not reflect the past conditions that have influenced genetic patterns [43]. This is likely particularly true for short-lived species that undergo continual population fluctuations. Many of our study species show substantial fluctuations in relation to fire $[48,49]$, and lack of fire history data across our study populations may hamper our ability to understand geographic patterns of genetic variation. Past events such as bottlenecks, founder events, low effective population sizes, and local extinctions may also have affected patterns of genetic variation in idiosyncratic ways $[89,90]$.

Unmeasured effects, such as habitat and matrix quality [91], low sample size, and limited genetic variation, could have helped improve the statistical signals in our analyses Limited genetic variation and low statistical power due to a small number of available populations for some of our species probably constrain our ability to detect patterns. Although we included an unusually large number of populations in our study, and in many cases all known populations, small numbers of populations for some species still hamper the analysis. Population numbers were particularly small for D. frutescens and E. cuneifolium, two species for which we found no link between geographic and genetic variables. In addition, low genetic variation is typical for narrow endemics $[92,93]$ including our study species [44] and reduces the power to detect trends. Therefore, we suggest that population size and landscape variables may be particularly unsuccessful in predicting genetic variation when species are narrowly endemic.

4.2. Past and Current Landscape Effects on Genetic Variation. We predicted that presettlement landscape structure for our suite of study species would have a stronger influence on genetic variation than extant landscape structure. However, we found little effect of landscape structure at either time on genetic variation.

Few studies have explicitly compared past and extant landscapes for their effects on landscape genetic structure, as we attempted in this study. Studies on bush crickets and butterflies have found that past landscape configuration and metapopulation structure, respectively, affected pairwise genetic similarities [94, 95]. In alpine meadow-dwelling butterflies, both contemporary and past (40 year) forest covers had effects on genetic patterns, with past cover affecting expected heterozygosity [96]. In wood frogs, populations underwent rapid genetic shifts in response to shifts in recent landscape structure [97]. However, in a ground beetle, habitat fragmentation did not explain current genetic structure [98]. In plants, the signature of historical habitat connectivity has been detected in several studies. For example, genetic diversity in Anthyllis vulneraria was more closely related to current fragment area and population size than to historical landscape configuration [33]. For Globularia bisnagarica, historical landscape structure and its influence on gene flow are thought responsible for the genetic similarity of currently fragmented populations [20]. Likewise, genetic structure of remnant populations of the endangered shrub Grevillea caleyi continued to reflect fine-scale genetic structure present before fragmentation [99]. These two studies attribute the continued influence of historical landscapes to a lag in the influence of contemporary mutation and drift in shaping population structure. This lag is brought about through long generation time, overlapping generations, and dormant seed banks.

4.3. Conclusions/Conservation Implications. Genetic variation is an increasingly important criterion in reserve design [100]. In our case, conservation strategies for most of these species are not well informed by our genetic data. Neither population size nor landscape factors are generally useful to identify the populations most critical for conservation of genetic variation. However, the best candidates for this inference may be long-lived, resprouting species such as L. ohlingerae and N. brittoniana, for which relatively stable population sizes provide more predictive power. In this study these species showed some relationship of genetic variation to the current and past landscape.

If direct identification of critical sites for conservation of genetic variation is not possible, alternative approaches for identifying sites are necessary. One alternative approach for prioritizing Lake Wales Ridge scrub habitat for conservation is based on the cumulative gain for multiple species and on the irreplaceability of sites for the rarest species $[59,70]$. Acquisition of the top eight unprotected sites recommended by these authors for conservation would result in the additional protection of five populations of $N$. brittoniana, four of L. ohlingerae, three of H. cumulicola, two of $W$. carteri, and one of $D$. frutescens. Only E. cuneifolium does not occur in any of these sites [59]. Although the populations so identified [60] are worthy of protection, our allozyme data do not specifically support the selection of these particular sites if increasing genetic variation of protected populations is a conservation goal. None have unique alleles and, in all cases, alleles per polymorphic locus and expected heterozygosity are within the $90 \%$ confidence intervals for these values across all populations. Prioritizing sites to maximize the number of species captured does not seem to also maximize capture of genetic variation in this analysis. 
Our results are consistent with much of the literature in suggesting that generalizations about patterns in genetic (allozyme) variability cannot always be predicted from landscape variables. In our case, we assumed that presettlement distributions included occupation of all sites with suitable soils. More complex, realistic landscape variables (e.g., detailed information on fire histories, not available for this landscape) might contribute to better prediction of genetic variation. Likewise, alternative types of genetic data (microsatellite or quantitative traits) might show stronger patterns in relation to the landscape. Nonetheless, as others have found, we have shown that ecological and landscape data are not necessarily consistent predictors of genetic variation. Genetic variation is also likely to be affected by climate change, for example, in the ways that climate change and habitat fragmentation may interact to affect phenology and demography [101]. As landscapes and the genetics of populations are still in considerable flux, new approaches to investigate of their linkages will be needed to improve understanding and predictability.

\section{Acknowledgments}

The authors thank Craig Young, Stacey Halpern, Deborah Graves, Margie Mayfield, George Landman, Joyce Voneman, Dawn Berry, Pedro Quintana-Ascencio, Jose Luis Hierro, Christina Casado, Helen Violi, Kelly McConnell, Sanyaalak Burkhart, Owen Boyle, Satya Maliakal-Witt, Kurt Reinhart, Erica Goss, Matt Finer, Patrick McIntyre, Nancy Kohfeldt, Marina Morales-Hernandez, and Hilary Swain for help in collecting data, Halle McKinney, Aaron Mast, Bill Thornbert, Jennifer Copeland, and Matt Halfhill for assistance in allozyme analyses, and Pedro Quintana-Ascencio for assistance in data analysis. They also thank the various landowners who provided permission for them to access populations for genetic sampling. Steve Christman's work provided many of the species locations used in this project. Suggestions from Pedro Quintana-Ascencio, Christine Hawkes, Margaret Evans, and several reviewers improved this paper. Support was provided by The Nature Conservancy's Ecosystem Research Program, the Florida Division of Forestry, Archbold Biological Station, Butler University, and the Florida Chapter of The Nature Conservancy.

\section{References}

[1] M. C. Neel, "Patch connectivity and genetic diversity conservation in the federally endangered and narrowly endemic plant species Astragalus albens (Fabaceae)," Biological Conservation, vol. 141, no. 4, pp. 938-955, 2008.

[2] N. C. Ellstrand and D. R. Elam, "Population genetic conseqences of small population size: implications for plant conservation," Annual Review of Ecology and Systematics, vol. 24, pp. 217-242, 1993.

[3] R. Leimu, P. Mutikainen, J. Koricheva, and M. Fischer, "How general are positive relationships between plant population size, fitness and genetic variation?" Journal of Ecology, vol. 94, no. 5, pp. 942-952, 2006.
[4] G. M. Crutsinger, M. D. Collins, J. A. Fordyce, Z. Gompert, C. C. Nice, and N. J. Sanders, "Plant genotypic diversity predicts community structure and governs an ecosystem process," Science, vol. 313, no. 5789, pp. 966-968, 2006.

[5] A. R. Hughes, B. D. Inouye, M. T. J. Johnson, N. Underwood, and M. Vellend, "Ecological consequences of genetic diversity," Ecology Letters, vol. 11, pp. 609-623, 2008.

[6] R. Holderegger, U. Kamm, and F. Gugerli, "Adaptive vs. neutral genetic diversity: implications for landscape genetics," Landscape Ecology, vol. 21, no. 6, pp. 797-807, 2006.

[7] D. H. Reed and R. Frankham, "Correlation between fitness and genetic diversity," Conservation Biology, vol. 17, no. 1, pp. 230-237, 2003.

[8] J. L. Hamrick and M. J. W. Godt, "Allozyme diversity in plant species," in Plant Population Genetics, Breeding, and Genetic Resources, A. H. D Brown, M. T. Clegg, A. H. Kahler, and B. S. Weir, Eds., pp. 43-64, Sinauer Associates, Sunderland, Mass, USA, 1989.

[9] M. J. W. Godt and J. L. Hamrick, "Genetic diversity in rare southeastern plants," Natural Areas Journal, vol. 21, pp. 6170, 2001.

[10] R. Aguilar, M. Quesada, L. Ashworth, Y. Herrerias-Diego, and J. Lobo, "Genetic consequences of habitat fragmentation in plant populations: susceptible signals in plant traits and methodological approaches," Molecular Ecology, vol. 17, no. 24, pp. 5177-5188, 2008.

[11] A. Young, T. Boyle, and T. Brown, "The population genetic consequences of habitat fragmentation for plants," Trends in Ecology and Evolution, vol. 11, no. 10, pp. 413-418, 1996.

[12] I. Hensen and C. Oberprieler, "Effects of population size on genetic diversity and seed production in the rare Dictamnus albus (Rutaceae) in central Germany," Conservation Genetics, vol. 6, no. 1, pp. 63-73, 2005.

[13] N. J. Ouborg, P. Vergeer, and C. Mix, "The rough edges of the conservation genetics paradigm for plants," Journal of Ecology, vol. 94, no. 6, pp. 1233-1248, 2006.

[14] O. Honnay and H. Jacquemyn, "Susceptibility of common and rare plant species to the genetic consequences of habitat fragmentation," Conservation Biology, vol. 21, no. 3, pp. 823831, 2007.

[15] K. Hirayama, K. Ishida, S. Setsuko, and N. Tomaru, "Reduced seed production, inbreeding, and pollen shortage in a small population of a threatened tree, Magnolia stellata," Biological Conservation, vol. 136, no. 2, pp. 315-323, 2007.

[16] F. A. Vieira and D. Carvalho, "Genetic structure of an insectpollinated and bird-dispersed tropical tree in vegetation fragments and corridors: implications for conservation," Biodiversity and Conservation, vol. 17, no. 10, pp. 2305-2321, 2008.

[17] S. M. Prober and A. H. D. Brown, "Conservation of the grassy white box woodlands: population genetics and fragmentation of Eucalyptus albens," Conservation Biology, vol. 8, pp. 1003-1013, 1996.

[18] K. Ritland, L. D. Meagher, D. G. W. Edwards, and Y. A. ElKassaby, "Isozyme variation and the conservation genetics of Garry oak," Canadian Journal of Botany, vol. 83, pp. 14781487, 2005.

[19] K. Vandepitte, H. Jacquemyn, I. Roldán-Ruiz, and O. Honnay, "Landscape genetics of the self-compatible forest herb Geum urbanum: effects of habitat age, fragmentation and local environment," Molecular Ecology, vol. 16, no. 19, pp. 4171-4179, 2007. 
[20] O. Honnay, D. Adriaens, E. Coart, H. Jacquemyn, and I. Roldán-Ruiz, "Genetic diversity within and between remnant populations of the endangered calcareous grassland plant Globularia bisnagarica L.," Conservation Genetics, vol. 8, no. 2, pp. 293-303, 2007.

[21] M. B. Silva, M. Kanashiro, A. Y. Ciampi, I. Thompson, and A. M. Sebbenn, "Genetic effects of selective logging and pollen gene flow in a low-density population of the dioecious tropical tree Bagassa guianensis in the Brazilian Amazon," Forest Ecology and Management, vol. 255, no. 5-6, pp. 15481558, 2008.

[22] M. D. Loveless and J. L. Hamrick, "Genetic organization and evolutionary history in two North American species of Cirsium," Evolution, vol. 42, pp. 254-265, 1988.

[23] T. T. J. Armstrong and P. J. DeLange, "Conservation genetics of the Hebe speciosa (Plantaginaeceae) an endangered New Zealand shrub," Botanical Journal of the Linnean Society, vol. 149, pp. 229-239, 2005.

[24] P. O. Lewis and D. J. Crawford, "Pleistocene refugium endemics exhibit greater allozymic diversity than widespread congeners in the genus Polygonella (Polygonaceae)," American Journal of Botany, vol. 82, no. 2, pp. 141-149, 1995.

[25] S. Manel, M. K. Schwartz, G. Luikart, and P. Taberlet, "Landscape genetics: combining landscape ecology and population genetics," Trends in Ecology and Evolution, vol. 18, no. 4, pp. 189-197, 2003.

[26] R. W. Dolan, "Patterns of isozyme variation in relation to population size, isolation, and phytogeographic history in royal catchfly (Silene regia, Caryophyllaceae)," American Journal of Botany, vol. 81, no. 8, pp. 965-972, 1994.

[27] D. A. Levin, "Genetic variation and divergence in a disjunct Phlox," Evolution, vol. 38, no. 1, pp. 223-225, 1984.

[28] C.-S. Chang, H. Kim, T.-Y. Park, and M. Maunder, "Low levels of genetic variation among southern peripheral populations of the threatened herb, Leontice microrhyncha (Berberidaceae) in Korea," Biological Conservation, vol. 119, no. 3, pp. 387-396, 2004.

[29] A. Wroblewska, "From the center to the margins of geographical range: molecular history of steppe plant Iris aphylla L. in Europe," Plant Systematics and Evolution, vol. 272, no. 1-4, pp. 49-65, 2008.

[30] C. G. Eckert, K. E. Samis, and S. C. Lougheed, "Genetic variation across species' geographical ranges: the centralmarginal hypothesis and beyond," Molecular Ecology, vol. 17, no. 5, pp. 1170-1188, 2008.

[31] J. A. Hamilton and C. G. Eckert, "Population genetic consequences of geographic disjunction: a prairie plant isolated on Great Lakes alvars," Molecular Ecology, vol. 16, no. 8, pp. 1649-1660, 2007.

[32] T. M. Culley and T. C. Grubb Jr., "Genetic effects of habitat fragmentation in Viola pubescens (Violaceae), a perennial herb with chasmogamous and cleistogamous flowers," Molecular Ecology, vol. 12, no. 11, pp. 2919-2930, 2003.

[33] O. Honnay, E. Coart, J. Butaye, D. Adriaens, S. Van Glabeke, and I. Roldán-Ruiz, "Low impact of present and historical landscape configuration on the genetics of fragmented Anthyllis vulneraria populations," Biological Conservation, vol. 127, no. 4, pp. 411-419, 2006.

[34] J. D. DiBattista, "Patterns of genetic variation in anthropogenically impacted populations," Conservation Genetics, vol. 9, pp. 141-156, 2008.
[35] A. P. Dobson, J. P. Rodriguez, W. M. Roberts, and D. S. Wilcove, "Geographic distribution of endangered species in the United States," Science, vol. 275, no. 5299, pp. 550-553, 1997.

[36] J. C. Estill and M. B. Cruzan, "Phytogeography of rare plant species endemic to the southeastern United States," Castanea, vol. 66, no. 1-2, pp. 3-23, 2001.

[37] A. M. Clark, B. W. Bowen, and L. C. Branch, "Effects of natural habitat fragmentation on an endemic scrub lizard (Sceloporus woodi): a historical perspective based on a mitochondrial DNA gene genealogy," Molecular Ecology, vol. 8, no. 7, pp. 1093-1104, 1999.

[38] D. B. McDonald, W. K. Potts, J. W. Fitzpatrick, and G. E. Woolfenden, "Contrasting genetic structures in sister species of North American scrub-jays," Proceedings of the Royal Society B, vol. 266, no. 1424, pp. 1117-1125, 1999.

[39] E. S. Menges, "Ecology and conservation of Florida scrub," in The Savanna, Barren, and Rock Outcrop Communities of North America, R. C. Anderson, J. S. Fralish, and J. Baskin, Eds., pp. 4-27, Cambridge University Press, New York, NY, USA, 1999.

[40] D. B. Mcdonald and J. L. Hamrick, "Genetic variation in some plants of Florida scrub," American Journal of Botany, vol. 83, no. 1, pp. 21-27, 1996.

[41] K. C. Parker and J. L. Hamrick, "Genetic variation in sand pine (Pinus clausa)," Canadian Journal of Forest Research, vol. 26, no. 2, pp. 244-254, 1996.

[42] M. J. W. Godt, T. Race, and J. L. Hamrick, "A population genetic analysis of Ziziphus celata, an endangered Florida shrub," Journal of Heredity, vol. 88, pp. 531-533, 1997.

[43] R. W. Dolan, R. Yahr, E. S. Menges, and M. D. Halfhill, "Conservation implications of genetic variation in three rare species endemic to Florida Rosemary scrub," American Journal of Botany, vol. 86, no. 11, pp. 1556-1562, 1999.

[44] R. S. Menges, R. W. Dolan, R. Yahr, and D. R. Gordon, "Comparative genetics of seven plants endemic to Florida's Lake Wales Ridge," Castanea, vol. 66, no. 1-2, pp. 98-114, 2001.

[45] K. C. Parker, J. L. Hamrick, A. J. Parker, and J. D. Nason, "Fine-scale genetic structure in Pinus clausa (Pinaceae) populations: effects of disturbance history," Heredity, vol. 87, pp. 99-113, 2001.

[46] C. W. Weekley, T. L. Kubisiak, and T. M. Race, "Genetic impoverishment and cross-incompatibility in remnant genotypes of Ziziphus celata (Rhamnaceae), a rare shrub endemic to the Lake Wales Ridge, Florida," Biodiversity and Conservation, vol. 11, no. 11, pp. 2027-2046, 2002.

[47] R. W. Dolan, R. Yahr, and E. S. Menges, "Population genetic structure in Nolina brittoniana (Agavaceae), a plant endemic to the central ridges of Florida," Southeastern Naturalist, vol. 3, no. 1, pp. 25-36, 2004.

[48] E. S. Menges, P. F. Quintana Ascencio, C. W. Weekley, and O. G. Gaoue, "Population viability analysis and fire return intervals for an endemic Florida scrub mint," Biological Conservation, vol. 127, no. 1, pp. 115-127, 2006.

[49] E. S. Menges and P. F. Quintana-Ascencio, "Population viability with fire in Eryngium cuneifolium: deciphering a decade of demographic data," Ecological Monographs, vol. 74, no. 1, pp. 79-99, 2004.

[50] P. F. Quintana-Ascencio, E. S. Menges, and C. W. Weekley, "A fire-explicit population viability analysis of Hypericum cumulicola in Florida rosemary scrub," Conservation Biology, vol. 17, no. 2, pp. 433-449, 2003. 
[51] C. W. Weekley, J. Tucker, S. Valligny, and E. S. Menges, "Germination ecology of Liatris ohlingerae (S.F. Blake) B.L. Rob. (Asteraceae), an endangered herb endemic to Florida scrub," Castanea, vol. 73, pp. 235-250, 2008.

[52] P. F. Quintana-Ascencio, E. S. Menges, C. W. Weekley, M. Kelrick, and B. Pace-Aldana, "Alternative demographic models predicting population dynamics in the fluctuating annual Warea carteri," Population Ecology. In revision.

[53] M. E. K. Evans, R. W. Dolan, E. S. Menges, and D. R. Gordon, "Genetic diversity and reproductive biology in Warea carteri (Brassicaceae), a narrowly endemic Florida scrub annual," American Journal of Botany, vol. 87, no. 3, pp. 372-381, 2000.

[54] E. S. Menges, C. W. Weekley, S. I. Hamze, and R. L. Pickert, "Soil preferences for federally-listed plants on the Lake Wales Ridge in Highlands County, Florida," Florida Scientist, vol. 70, pp. 24-39, 2007.

[55] E. S. Menges and C. V. Hawkes, "Interactive effects of fire and microhabitat on plants of Florida scrub," Ecological Applications, vol. 8, no. 4, pp. 935-946, 1998.

[56] W. G. Abrahamson, A. F. Johnson, J. N. Layne, and P. A. Peroni, "Vegetation of the Archbold Biological Station, Florida: an example of the southern Lake Wales Ridge," Florida Scientist, vol. 47, pp. 209-250, 1984.

[57] P. F. Quintana-Ascencio and E. S. Menges, "Inferring metapopulation dynamics from patch-level incidence of Florida scrub plants," Conservation Biology, vol. 10, no. 4, pp. 1210-1219, 1996.

[58] W. A. Watts, "The later Quaternary record of vegetation from Lake Annie, south-central Florida," Geology, vol. 3, pp. 344346, 1975.

[59] W. R. Turner, D. S. Wilcove, and H. M. Swain, "State of the scrub. Conservation progress, management responsibilities, and land acquisition priorities for imperiled species of Florida's Lake Wales Ridge," Archbold Biological Station Report, 2006, http://www.archbold-station.org/abs/publicationsPDF/Turner_etal-2006-StateotScrub.pdf.

[60] P. A. Peroni and W. G. Abrahamson, "A rapid method for determining losses of native vegetation," Natural Areas Journal, vol. 5, pp. 20-24, 1985.

[61] E. S. Menges and D. R. Gordon, "Three levels of monitoring intensity for rare plant species," Natural Areas Journal, vol. 16, no. 3, pp. 227-237, 1996.

[62] L. M. Wolfe, "Inbreeding depression in Hydrophyllum appendiculatum: role of maternal effects, crowding, and parental mating history," Evolution, vol. 47, no. 2, pp. 374-386, 1993.

[63] A. T. Lombard, R. M. Cowling, R. L. Pressey, and P. J. Mustartf, "Reserve selection in a species-rich and fragmented landscape on the Agulhas Plain, South Africa," Conservation Biology, vol. 11, no. 5, pp. 1101-1116, 1997.

[64] M. Cabeza, M. B. Araújo, R. J. Wilson, C. D. Thomas, M. J. R. Cowley, and A. Moilanen, "Combining probabilities of occurrence with spatial reserve design," Journal of Applied Ecology, vol. 41, no. 2, pp. 252-262, 2004.

[65] J. C. Williams, C. S. ReVelle, and S. A. Levin, "Using mathematical optimization models to design nature reserves," Frontiers in Ecology and Environment, vol. 2, pp. 98-105, 2004.

[66] C. W. Weekley, E. S. Menges, and R. L. Pickert, "An ecological map of Florida's Lake Wales Ridge: a new boundary delineation and an assessment of post-Columbian habitat loss," Florida Scientist, vol. 71, pp. 45-64, 2008.
[67] W. R. Turner, D. S. Wilcove, and H. M. Swain, "Assessing the effectiveness of reserve acquisition programs in protecting rare and threatened species," Conservation Biology, vol. 20, no. 6, pp. 1657-1669, 2006.

[68] D. L. Swofford and R. B. Selander, BIOSYS-1. A Computer Program for the Analysis of Allelic Variation in Population Genetics and Biochemical Systematics, Illinois Natural History Survey, Champaign, Ill, USA, 1989.

[69] M. E. K. Evans, E. S. Menges, and D. R. Gordon, "Reproductive biology of three sympatric endangered plants endemic to Florida scrub," Biological Conservation, vol. 111, no. 2, pp. 235-246, 2003.

[70] M. Partel, A. Helm, N. Ingerpuu, U. Reier, and E.-L. Tuvi, "Conservation of Northern European plant diversity: the correspondence with soil pH," Biological Conservation, vol. 120, no. 4, pp. 525-531, 2004.

[71] J. Cavender-Bares, K. Kitajima, and F. A. Bazzaz, "Multiple trait associations in relation to habitat differentiation among 17 Floridian oak species," Ecological Monographs, vol. 74, no. 4, pp. 635-662, 2004.

[72] L. J. Carter, D. Lewis, and L. Crockett, Soil survey of Highlands County, Florida, Soil Conservation Service, USDA, Gainesville, Fla, USA, 1989.

[73] E. A. Fernald and D. J. Patton, Water Resources Atlas of Florida, Florida State University, 1984.

[74] E. A. Fernald and E. D. Purdum, Atlas of Florida, University Press of Florida, Gainesville, Fla, USA, 1992.

[75] T. Schmidt, P. Arens, M. J. M. Smulders, et al., "Effects of landscape structure on genetic diversity of Geum urbanum L. populations in agricultural landscapes," Flora, vol. 204, no. 7, pp. 549-559, 2009.

[76] I. Hanski and C. D. Thomas, "Metapopulation dynamics and conservation: a spatially explicit model applied to butterflies," Biological Conservation, vol. 68, no. 2, pp. 167180, 1994.

[77] SPSS 2002. SPSS for Windows, Release 11.5.0.

[78] A. Young, T. Boyle, and T. Brown, "The population genetic consequences of habitat fragmentation for plants," Trends in Ecology and Evolution, vol. 11, no. 10, pp. 413-418, 1996.

[79] S. Cuartas-Hernández and J. Núñez-Farfán, "The genetic structure of the tropical understory herb Dieffenbachia seguine L. before and after forest fragmentation," Evolutionary Ecology Research, vol. 8, no. 6, pp. 1061-1075, 2006.

[80] A. G. Young, J. H. Hill, B. G. Murray, and R. Peakall, "Breeding system, genetic diversity and clonal structure in the sub-alpine forb Rutidosis leiolepis F. Muell. (Asteraceae)," Biological Conservation, vol. 106, no. 1, pp. 71-78, 2002.

[81] M. C. Neel and N. C. Ellstrand, "Conservation of genetic diversity in the endangered plant Eriogonum ovalifolium var. vineum (Polygonaceae)," Conservation Genetics, vol. 4, no. 3, pp. 337-352, 2003.

[82] K. A. Cariaga, C. E. Lewis, J. Maschinski, S. J. Wright, and J. Francisco-Ortega, "Patterns of genetic diversity in the critically endangered Florida key endemic Consolea corallicola small (Cactaceae): evidence from inter-simple sequence repeat (ISSRs) DNA polymorphisms," Caribbean Journal of Science, vol. 41, no. 2, pp. 225-233, 2005.

[83] C. B. Fenster, "Gene flow in Chamaecrista fasciculata (Leguminosae). I. Gene dispersal," Evolution, vol. 45, no. 2, pp. 398-409, 1991.

[84] J. Schmitt, "Density-dependent pollinator foraging, flowering phenology, and temporal pollen dispersal patterns in Linanthus bicolor," Evolution, vol. 37, no. 6, pp. 1247-1257, 1983. 
[85] X. Vekemans and O. J. Hardy, "New insights from finescale spatial genetic structure analyses in plant populations," Molecular Ecology, vol. 13, no. 4, pp. 921-935, 2004.

[86] R. Frankham, "Genetics and extinction," Biological Conservation, vol. 126, no. 2, pp. 131-140, 2005.

[87] A. J. Lowe, D. Boshier, M. Ward, C. F. E. Bacles, and C. Navarro, "Genetic resource impacts of habitat loss and degradation; reconciling empirical evidence and predicted theory for neotropical trees," Heredity, vol. 95, no. 4, pp. 255273, 2005.

[88] L. Fahrig, "Effects of habitat fragmentation on biodiversity," Annual Review of Ecology, Evolution, and Systematics, vol. 34, pp. 487-515, 2003.

[89] K. Schmidt and K. Jensen, "Genetic structure and AFLP variation of remnant populations in the rare plant Pedicularis palustris (Scrophulariaceae) and its relation to population size and reproductive components," American Journal of Botany, vol. 87, no. 5, pp. 678-689, 2000.

[90] L. Allphin, N. Brian, and T. Matheson, "Reproductive success and genetic divergence among varieties of the rare and endangered Astragalus cremnophylax (Fabaceae) from Arizona, USA," Conservation Genetics, vol. 6, no. 5, pp. 803821, 2005.

[91] N. S. G. Williams, J. W. Morgan, M. A. McCarthy, and M. J. McDonnell, "Local extinction of grassland plants: the landscape matrix is more important than patch attributes," Ecology, vol. 87, no. 12, pp. 3000-3006, 2006.

[92] M. A. Gitzendanner and P. S. Soltis, "Patterns of genetic variation in rare and widespread congeners," American Journal of Botany, vol. 87, pp. 783-792, 2000.

[93] J. L. Hamrick, M. J. W. Godt, D. A. Murawski, and M. D. Loveless, "Correlations between species traits and allozyme diversity: implications for conservation biology," in Genetics and Conservation of Rare Plants, D. A. Falk and K. E. Holsinger, Eds., pp. 75-86, Oxford University Press, New York, NY, USA, 1991.

[94] S. I. J. Holzhauer, K. Ekschmitt, A.-C. Sander, J. Dauber, and V. Wolters, "Effect of historic landscape change on the genetic structure of the bush-cricket Metrioptera roeseli," Landscape Ecology, vol. 21, no. 6, pp. 891-899, 2006.

[95] L. Orsini, J. Corander, A. Alasentie, and I. Hanski, "Genetic spatial structure in a butterfly metapopulation correlates better with past than present demographic structure," Molecular Ecology, vol. 17, no. 11, pp. 2629-2642, 2008.

[96] N. Keyghobadi, J. Roland, S. F. Matter, and C. Strobeck, "Among- and within-patch components of genetic diversity respond at different rates to habitat fragmentation: an empirical demonstration," Proceedings of the Royal Society B, vol. 272, no. 1562, pp. 553-560, 2005.

[97] A. J. Zellmer and L. L. Knowles, "Disentangling the effects of historic vs. contemporary landscape structure on population genetic divergence," Molecular Ecology, vol. 18, no. 17, pp. 3593-3602, 2009.

[98] C. Drees, A. Matern, J.-Y. Rasplus, H. Terlutter, T. Assmann, and F. Weber, "Microsatellites and allozymes as the genetic memory of habitat fragmentation and defragmentation in populations of the ground beetle Carabus auronitens (Col., Carabidae)," Journal of Biogeography, vol. 35, no. 10, pp. 1937-1949, 2008.

[99] T. M. Llorens, D. J. Ayre, and R. J. Whelan, "Evidence for ancient genetic subdivision among recently fragmented populations of the endangered shrub Grevillea caleyi (Proteaceae)," Heredity, vol. 92, no. 6, pp. 519-526, 2004.
[100] M. C. Neel and M. P. Cummings, "Genetic consequences of ecological reserve design guidelines: an empirical investigation," Conservation Genetics, vol. 4, no. 4, pp. 427-439, 2003.

[101] S. Matesanz, A. Escudero, and F. Valladares, "Impact of three global change drivers on a Mediterranean shrub," Ecology, vol. 90, no. 9, pp. 2609-2621, 2009. 

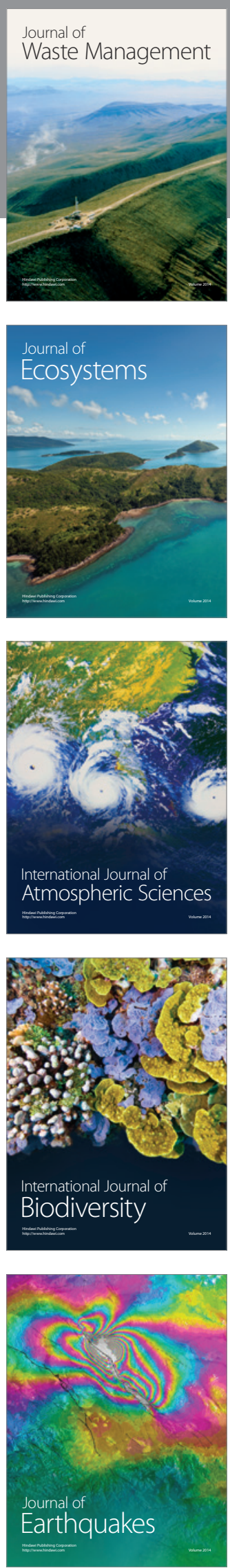
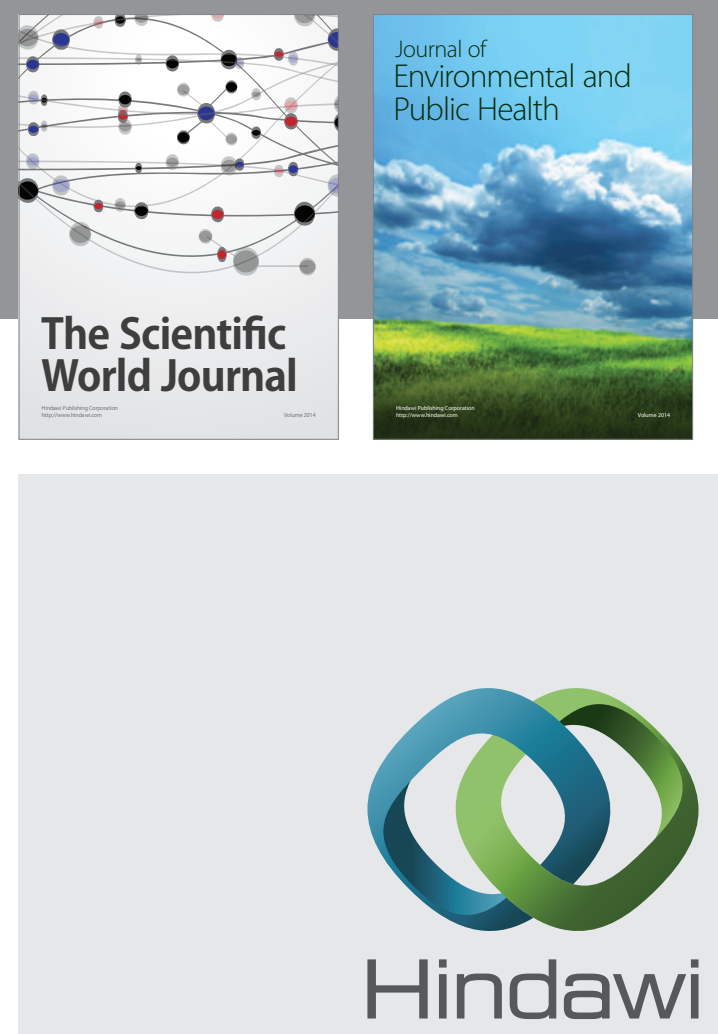

Submit your manuscripts at

http://www.hindawi.com
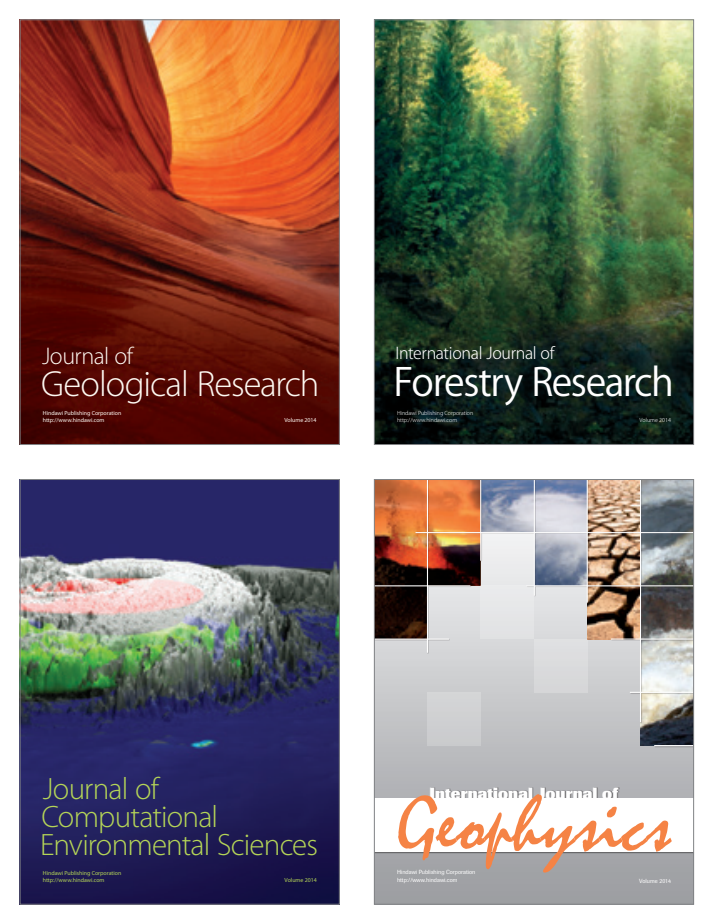
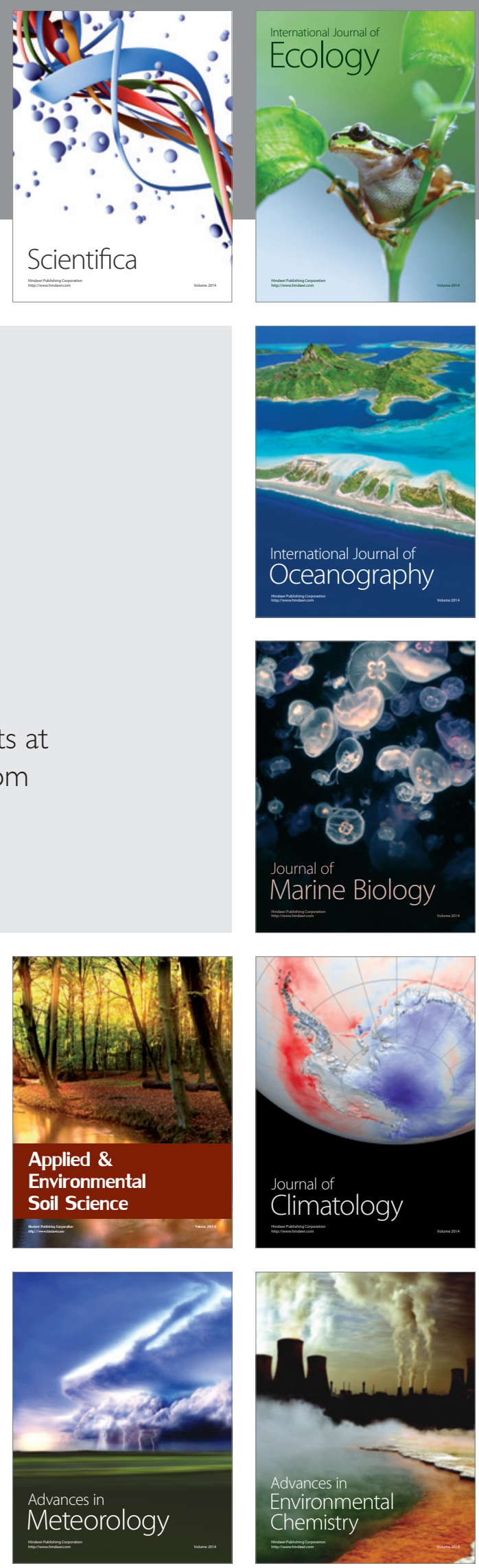